\title{
PSA Level Twenty to One Hundred Fifty or Greater
}

National Cancer Institute

\section{Source}

National Cancer Institute. PSA Level Twenty to One Hundred Fifty or Greater. NCI

Thesaurus. Code C158930.

A blood concentration of prostate specific antigen between $20 \mathrm{ng} / \mathrm{mL}$ and $150 \mathrm{ng} / \mathrm{mL}$ or greater. 